\title{
Myocardial Adaptation in Pseudohypoxia: Signaling and Regulation of mPTP via Mitochondrial Connexin 43 and Cardiolipin
}

\author{
Miroslav Ferko *, Natália Andelová, Barbara Szeiffová Bačová and Magdaléna Jašová \\ Center of Experimental Medicine, Slovak Academy of Sciences, Institute for Heart Research, Dúbravská cesta 9, \\ 84104 Bratislava, Slovakia; nat.andelova@gmail.com (N.A.); usrdbaca@savba.sk (B.S.B.); \\ jasovam@gmail.com (M.J.) \\ * Correspondence: usrdmife@savba.sk; Tel.: +421-907065665
}

Received: 7 November 2019; Accepted: 15 November 2019; Published: 17 November 2019

\begin{abstract}
Therapies intended to mitigate cardiovascular complications cannot be applied in practice without detailed knowledge of molecular mechanisms. Mitochondria, as the end-effector of cardioprotection, represent one of the possible therapeutic approaches. The present review provides an overview of factors affecting the regulation processes of mitochondria at the level of mitochondrial permeability transition pores $(\mathrm{mPTP})$ resulting in comprehensive myocardial protection. The regulation of MPTP seems to be an important part of the mechanisms for maintaining the energy equilibrium of the heart under pathological conditions. Mitochondrial connexin 43 is involved in the regulation process by inhibition of $\mathrm{mPTP}$ opening. These individual cardioprotective mechanisms can be interconnected in the process of mitochondrial oxidative phosphorylation resulting in the maintenance of adenosine triphosphate (ATP) production. In this context, the degree of mitochondrial membrane fluidity appears to be a key factor in the preservation of ATP synthase rotation required for ATP formation. Moreover, changes in the composition of the cardiolipin's structure in the mitochondrial membrane can significantly affect the energy system under unfavorable conditions. This review aims to elucidate functional and structural changes of cardiac mitochondria subjected to preconditioning, with an emphasis on signaling pathways leading to mitochondrial energy maintenance during partial oxygen deprivation.
\end{abstract}

Keywords: cardioprotection; mitochondria; mitochondrial permeability transition pores; mitochondrial connexin 43; cardiolipin

\section{Introduction}

Mitochondria are considered to be one of the most important organelles, not only in terms of their ability to control apoptosis [1] or necrosis [2], but also for their important participation in cardioprotection [3]. Mitochondria can cope with energy demanding situations due to their adaptability. The adaptation mechanisms of mitochondria are very important especially in the heart [4]. Cardiac mitochondria provide more than $90 \%$ of the total energy required for the cell [5]. Moreover, mitochondria are able to adapt to new conditions through signaling pathways affecting membrane remodeling, mitochondrial dynamics, or energy production [6,7].

Currently, many studies suggest that regulation of mitochondrial permeability transition pore (mPTP) opening plays a key role in the induction of cardioprotection [8-11]. Modulation of mitochondrial membrane fluidity through its major component, cardiolipin, or signalization via mitochondrial connexin $43(\mathrm{mtCx} 43)$ leads to myocardial energy maintenance under the conditions of reduced oxygen utilization. 
The common denominator of cardioprotection induction seems to be the exposure of the organism to oxygen limiting conditions [12]. The partial or complete absence of oxygen (hypoxia, anoxia) or damage of the respiratory chain affect the changes of biochemical and metabolic processes and induce remodeling of membrane systems [13]. A limited supply or damage in oxygen processing activates signaling pathways that result in structural and functional changes involved in the adaptation of myocardium to pathological conditions.

The mPTP, cardiolipin, and $\mathrm{mtCx} 43$ signaling pathways are calcium associated. Calcium $\left(\mathrm{Ca}^{2+}\right)$ ions as major inducers of mPTP opening show a high affinity to cardiolipin $[14,15]$. The process of hypoxia and subsequent reoxygenation also affect mPTP opening coupled with regulation of $\mathrm{Ca}^{2+}$ handling and cardiolipin oxidation [16]. Similarly, $\mathrm{mtCx} 43$ forms $\mathrm{Ca}^{2+}$ permeable hemichannels allowing $\mathrm{Ca}^{2+}$ entry and triggering a permeable transition leading to cell death [17]. In the following parts of this review, we discuss the signaling pathways through $\mathrm{mPTP}$ regulation in cooperation with cardiolipin and $\mathrm{mtCx} 43$ leading to myocardial adaptation in pseudohypoxia.

\section{Cardioprotection and Mitochondrial Energetics}

Myocardium is highly dependent on sufficient oxygen supply. For this reason, cardiac mitochondria must maintain adequate oxygen to continue oxidative phosphorylation [18-20]. Mitochondrial biogenesis is increased at the metabolically active site of the cell where the consumption of adenosine triphosphate (ATP) is increased [21,22]. Therefore, mitochondria occupy up to $35 \%$ of the cell volume of cardiomyocytes of heart ventricles [23-25]. The oxygen consumption varies depending on the physiological state of the organism [26]. Insufficient oxygen supply, characteristic of pathological situations, is reflected in the reduction of energy production in cardiac mitochondria $[22,27,28]$. Although cardiac mitochondria are the main energy source of cells, their dysfunction contributes to the development of a wide range of diseases $[29,30]$. The most common diseases, such as ischemic heart disease [31] or diabetes mellitus [32,33], create conditions in which the organism is exposed to a significant lack of oxygen. Partial (hypoxia) or complete (anoxia) absence of oxygen or the inability to use available oxygen due to damage of the mitochondrial respiratory chain (pseudohypoxia) well characterizes the disease of diabetes mellitus [34] and changes of several biochemical and metabolic processes [32]. Therefore, attention is required to develop new therapeutic approaches directed to mitochondria as target organelles triggering cardioprotection.

The principle of the new cardioprotective models is based on controlled oxygen restriction [35]. One of the first well known phenomena of cardioprotection is ischemic preconditioning (IPC), consisting of several repetitions of short ischemic and subsequent reperfusion episodes that reduce myocardial sensitivity before the next prolonged ischemic episode of the heart [36]. The duration of ischemia is crucial for the rate of myocardial damage [37]. While the early phase of ischemia causes reversible changes of cardiomyocyte and decreases the contractility of myocardium, prolonged ischemia (more than 20 to $30 \mathrm{~min}$ ) leads to irreversible changes in the metabolism, function, and ultrastructure of the heart [30].

Although many studies have confirmed the efficacy of the classical form of IPC [38-40], attention is drawn to an alternative method of controlled induction of short term non-lethal series of ischemic and subsequent reperfusion impulses on specific organs or tissues remote from the heart, known as remote ischemic preconditioning (RPC) [41]. This phenomenon provides protection of myocardium against lethal ischemic damage [42].

An insufficient oxygen supply and nutrients in cardiomyocytes is the main cause of heart ischemia/reperfusion (I/R) injury [43,44]. In a situation with a continuous lack of oxygen, anaerobic glycolysis is preferred [45]. A change in substrate preference used for energy production seems to be the key mechanism favorable for cells with a limited oxygen supply. This is one of the reasons why partial oxygen deprivation is the main factor used in experimental models for the induction of cardioprotection [46]. 


\section{Cardiac Mitochondrial Energetics in Partial Oxygen Deprivation}

Oxygen deprivation is reflected in specific metabolic changes that result in a balance disorder between fatty acids and glucose oxidation. The restriction of oxygen supply is reflected in changes in preferences for substrates used for energy production [47,48]. In comparison with fatty acid oxidation, a higher amount of ATP is produced by aerobic oxidation of glucose in relation to oxygen consumption [49]. Therefore, glucose is the preferred energy substrate. Despite the fact that fatty acids are less efficient energy substrates compared to glucose, fatty acids are the preferred source of energy in situations associated with impaired mitochondrial function, reduced respiration, and decreased ATP production, such as ischemia of the heart or diabetes mellitus [50].

Increasing oxidation of fatty acids in the heart reduces oxidation of glucose and vice versa. The oxidation of fatty acids increases nicotinamide adenine dinucleotide (NADH) and acetyl-CoA levels, which inhibit pyruvate dehydrogenase $(\mathrm{PDH})$ associated glucose metabolism reduction [51,52]. The process of mutual regulation of glucose and fatty acid metabolism is called the Randle cycle [53]. However, the predominance of fatty acid oxidation during reperfusion versus glucose oxidation negatively affects the activity of the heart $[48,54]$. Consequently, manipulating heart metabolism to redirect fatty acid oxidation during reperfusion to glucose utilization may constitute a proof-of-concept on how to preserve heart function after ischemia or hypoxia $[55,56]$.

When a sufficient supply of oxygen is ensured, glucose is metabolized by aerobic oxidation [57]. The PDH complex metabolizes glucose to acetyl-CoA, which then enters into the Krebs cycle [58]. A limited supply of oxygen causes phosphorylation of PDH subunits, i.e., $\mathrm{PDH}$ inactivation, which is reflected in the inability to metabolize glucose to pyruvate and acetyl-CoA. Then, glucose is metabolized by anaerobic glycolysis to lactate $[59,60]$. This process is used mainly by cancer cells that are permanently in anaerobic conditions [61]. Oxygen deprivation stimulates the overexpression of hypoxia-inducible factor $1 \alpha$ (HIF- $1 \alpha$ ) and inactivation of PDH through pyruvate dehydrogenase kinase 1 , resulting in the preference of anaerobic glucose oxidation [62-64]. This process in which the glucose metabolism is reprogrammed from aerobic to anaerobic is known as the Warburg effect [65]. Despite the fact that ATP production in anaerobic glycolysis is much lower, i.e., two molecules of ATP are produced by anaerobic glycolysis, but up to 36 molecules of ATP by the oxidative phosphorylation of one glucose molecule, anaerobic glycolysis is preferred due to low oxygen consumption [66]. Deletion of HIF- $1 \alpha$ affects heart function under normoxic conditions, despite the fact that the heart is protected by HIF-1 against hypoxia [32]. Since PDH and the electron transport chain of mitochondria are the major sources of reactive oxygen species (ROS), a preference for anaerobic glycolysis prevents the apoptosis of cancer cells [67,68]. Moreover, continuous production of ATP is ensured by constant glucose supply (malignancy or hyperglycemia) [69]. In addition, the process of anaerobic glycolysis is 100-times faster than oxidative phosphorylation [70]. A constant supply of small amounts of energy with a low oxygen consumption is advantageous for immediate energy supply [71,72]. Besides that, the function of mitochondria is considerably limited in affected cells; therefore, anaerobic glycolysis is the major mechanism of energy production. Since cancer cells are capable of increased proliferation even under these restricted conditions, we can consider that preference for anaerobic glycolysis is beneficial for cells exposed to hypoxia [66,73]. According to the above, we can suppose that cardiomyocytes from diabetic myocardium could be used to describe metabolic processes such as those of cancer cells [63]. Diabetic myocardium is characterized by a state of pseudohypoxia, as a result of electron transport chain damage associated with a limitation of oxidative phosphorylation and impairment of HIF-1 activation [32]. Pseudohypoxia is described as impaired cellular oxygen utilization capacity due to reduced levels of NAD, which may cause NADH accumulation with NADH/NAD redox imbalances [74,75]. Therefore, anaerobic glycolysis could also be advantageous for the cells of diabetic organisms [34,76]. Despite the known side effects of PDH inhibition, such as diabetes mellitus [58,77-79], metabolic syndrome [80], heart failure [81], and fatty liver [82], we can assume that cells of diabetic hearts use similar adaptation mechanisms to increase their survival. A sufficient supply of glucose ensures a prompt and continuous production of energy. These facts 
explain the advantage of anaerobic glycolysis in a diabetic heart [52]. Another important factor is age, which leads to dysregulation of molecular pathways linked to mitochondria. Increased apoptosis, declined autophagy, increased disruption of $\mathrm{MPTP}$, and worsened injury after hypoxic-ischemic insults are the results of aging. The age related decrease in NAD+ contributes to substrate starvation leading to a pseudohypoxic state [83].

\section{Metabolic Preconditioning}

Adaptation of the heart to altered metabolic conditions allows the maintenance of its function. It allows the heart to meet the requirements of the body effectively [84]. One of the most commonly used experimental models for the induction of metabolic preconditioning (MPC) is streptozotocin-induced diabetes mellitus with positive structural and metabolic changes present during its acute phase [84-88]. The acute stage of diabetes is characterized by the inhibition of insulin secretion and decreased signaling of insulin receptors in target cells [89]. After the seven days following streptozotocin administration, changes induced by diabetes mellitus are fully developed, without side complication characteristics for the chronic stage of the disease [90]. The acute phase of diabetes mellitus persists for the next three weeks [89].

The chronic phase of streptozotocin diabetes mellitus can be induced by a longer administration of streptozotocin, i.e., for more than 60 days. It is characterized by many complications, such as neuropathy, retinopathy, nephropathy, microangiopathy, etc. [91].

Despite the fact that diabetes mellitus causes extensive changes in the structure and function of cardiomyocytes, its impact is not necessarily entirely harmful. A short-term exposure of the heart to a high glucose concentration or diabetes mellitus has proven beneficial effects against ischemic insult $[92,93]$. The first evidence of a compensation effect due to diabetes was presented by a study pointing out a better recovery of contractility of a diabetic heart after an I/R injury [94].

The acute phase of MPC induced by diabetes is characterized not only by metabolic changes [84], but also by positively affecting the heart efficiency and its sensitivity to pathological stimuli, remodeling the cardiomyocyte membrane, as well as cardiac mitochondria $[95,96]$. Indeed, remodeling has a central role in maintaining or repairing the heart tissue [97].

\section{Involvement of Mitochondrial Connexin 43 in Cardioprotection}

It has been well established that the modulation of membrane channel protein "connexin 43" (Cx43), the most abundant connexin in the heart [98], could have various cardioprotective effects [99-102]. The association of six subunits of Cx43 results in the formation of hemichannel "connexon" [103]. After transportation in secretory vesicles to the plasma membrane, two opposing connexons from adjacent cells create the "Cx channel". Thousands of $\mathrm{Cx} 43$ channels aggregate into gap junction plaques at the intercalated disks $[104,105]$. This direct connection between two adjacent cells provides electrical and metabolic cell-to-cell coupling [106]. Cx43 hemichannels are not only precursors for Cx43 channels, but can also exist as non-junctional hemichannels at the plasma membrane and can contribute to volume regulation, to the release of ATP and NAD+ from the cytosol, and the activation of cell survival pathways [107]. In addition to predominantly localized Cx43 at the intercalated disks, $4 \%$ Cx43 is present in mitochondria due to translocation from cardiomyocytes $[108,109]$.

$\mathrm{MtCx} 43$ in the cardiomyocytes is situated in the inner mitochondrial membrane (IMM) of subsarcolemmal mitochondria (SSM) where it forms an mtCx43 hemichannel [110,111]. MtCx43 import to the IMM of SSM is mediated by the interaction between Cx43 with the heat shock protein 90 (HSP90) and translocase of the outer membrane 20 [109]. The physiological role of mtCx43 is not fully clarified, but some studies support its involvement in the regulation of $\mathrm{K}^{+}$fluxes [112], mitochondrial respiration [113], oxygen consumption [111,112], mitochondrial redox state [114], and in mitochondrial $\mathrm{Ca}^{2+}$ homeostasis [115] (Figure 1). In this context, it is understandable that $\mathrm{mtCx} 43$ is attributed to cardioprotection. 


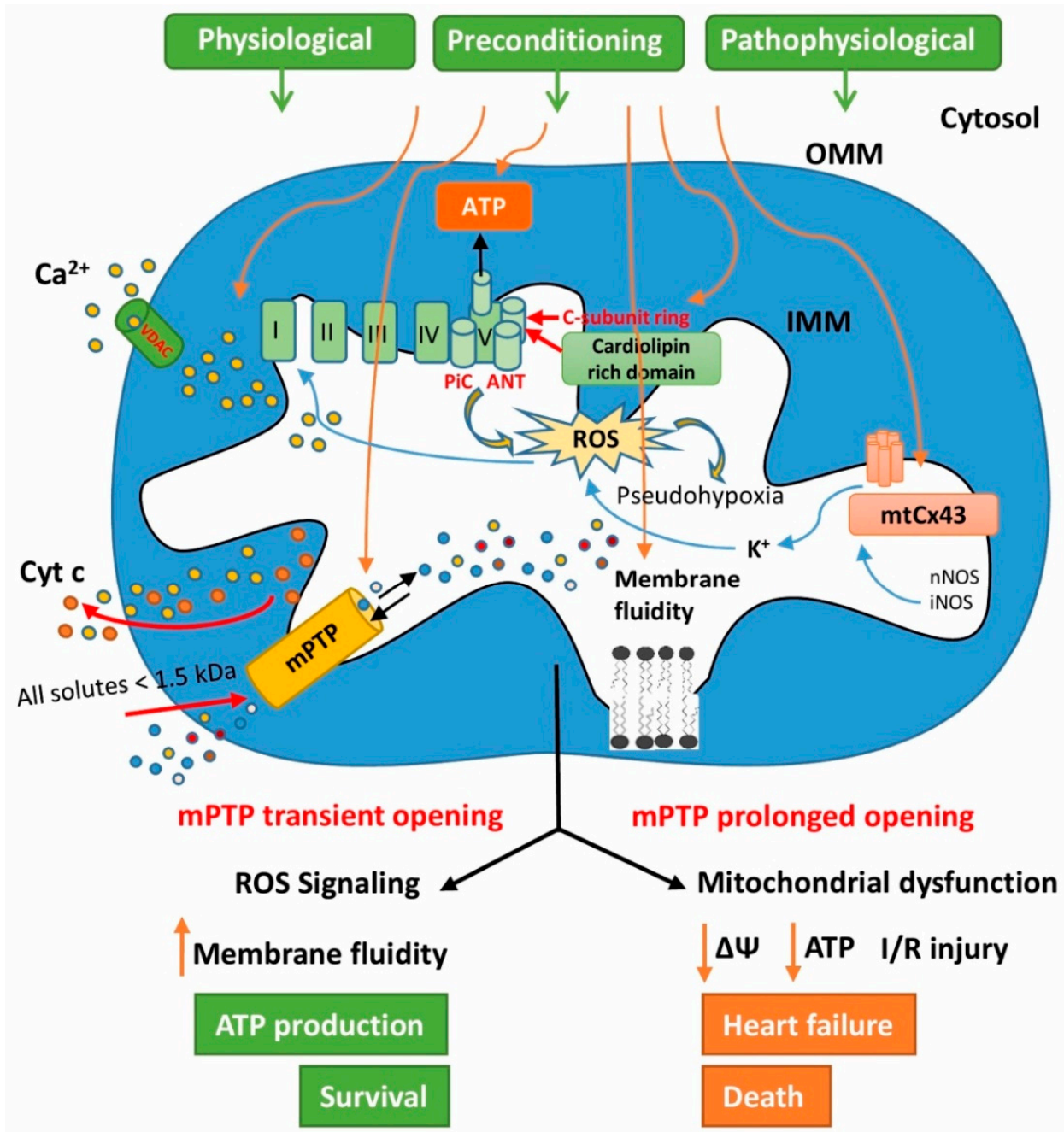

Figure 1. Diagram of signaling pathways affecting mitochondrial permeability transition pores (mPTP) regulation in preconditioned and pathological myocardium. For details, see the text.

The implication of $\mathrm{mtCx} 43$ in the cardioprotective pathway of IPC has been mostly elucidated $[109,111,116]$. The protein level of $\mathrm{mtC} \times 43$ very rapidly increased in response to IPC and was maintained for at least $90 \mathrm{~min}$ in a pig model of IPC [108], whereas attenuation of $\mathrm{mtCx} 43$ was associated with lost IPC cardioprotection [108]. Evidence that $\mathrm{mtCx} 43$ is implicated in this mechanism was also demonstrated in an experiment by Heinzel et al. in 2015, where pharmacological preconditioning by diazoxide mediated by gating of mitochondrial ATP sensitive potassium channels (KATP) and protein kinase $C$ activation [117] was repealed in cardiomyocytes isolated from mice with a reduced Cx43 level. Mitochondrial KATP channels have also a key role in mitochondrial physiology and potential effects on several pathological processes, thanks to their involvement in cellular energetic status by regulation of organelle volume and function [118].

Indeed, diazoxide affects the generation of ROS necessary in low amounts as trigger molecules of IPC [119]. In the experimental model of Cx43-deficient mice, nitric oxide (NO) production was significantly lower compared to wild type control mice [120]. Increased S-nitrosation of $\mathrm{mtCx} 43$ by IPC elevated mitochondrial permeability and subsequently ROS formation [121]. Moreover, diazoxide modulates the opening of the mPTP [122]. The relationship between mtCx43 and mPTP has been elucidated. In this study, pharmacological inhibition of $\mathrm{mtC} \times 43$ induced opening of $\mathrm{mPTP}$ in SSM by increased levels of $\mathrm{Ca}^{2+}$ [123]. Another study with IPC abolishment in which reduction of $\mathrm{mtCx} 43$ was induced by geldanamycin (which prevents translocation of $\mathrm{Cx} 43$ to mitochondria by blocking the HSP90 dependent pathway) confirmed that only $\mathrm{mtCx} 43$ is implicated in this cardioprotection [124]. 
$\mathrm{MtC} \times 43$ can also be implicated in cardioprotection by interaction with proteins related to mitochondrial fraction and metabolism. MtCx43 interacts with the apoptosis inducing factor (AIF) involved in oxidative phosphorylation and redox control. Interestingly, AIF deficient mice had the same pattern of changes in ROS generation and mitochondrial complex 1 activity as Cx43 deficient mice [113]. In cardiomyocytes with overexpression of Cx43, only complex I respiration was increased, while complex II remained unchanged [113]. A close relationship between $\mathrm{mtCx} 43$ and with anti- and pro-apoptosis markers Bcl-2 and Bax was observed. In this experiment, elevated levels of $\mathrm{mtC} \times 43$ were accompanied by the upregulation of $\mathrm{Bcl}-2$ and inhibition of Bax in the cardiac mitochondria after hypoxic postconditioning [125].

\section{The Role of Cardiolipin in Heart Mitochondrial Signaling}

Cardiolipin, as a unique phospholipid, is an important component of the IMM [126,127]. It is a relevant indicator of mitochondrial membrane fluidity damage [128]. Due to the localization of respiratory enzymes and oxidative phosphorylation in the IMM, maintaining a positive membrane fluidity remodeling is essential to ensure the bioenergetic processes of the cell [95,129-131] (Figure 1). The fluidity of the mitochondrial membrane is an important part of endogenous protective mechanisms, especially in pathological conditions such as diabetes mellitus [34], ischemia-reperfusion damage [132,133], and hypercholesterolemia [130]. Maintaining membrane fluidity under load conditions at the control level improves ATP transport from the mitochondrial matrix to the cytosol of cardiomyocytes [130]. The sustainability of phospholipid composition in the mitochondrial membrane results in the proper mitochondrial function and structure, phospholipid metabolism, and energy transport [134].

Changes in the composition of the cardiolipin structure, content, and acyl chain are associated with mitochondrial dysfunction in the tissues of certain pathophysiological conditions, including apoptosis [125], ischemia [135], I/R [136], in various stages of thyroid disease [137,138], diabetes mellitus [139], aging [140], and heart failure [135,141].

Cardiolipin is an oxidatively sensitive phospholipid, particularly to ROS [142], due to a high content of unsaturated fatty acids [143]. Oxidative damage of cardiolipin negatively affects the biochemical function of mitochondrial membranes [127], which is reflected in the alteration of the membrane fluidity, ion permeability, as well as the structure and function of the electron transport chain. These alterations lead to a reduced oxidative phosphorylation efficacy of mitochondria [144,145].

Cardiolipin contributes to the protein function in the IMM and maintains the integrity and flow of the electron transport chain, including anionic carriers and respiratory chain complexes [146,147]. Cardiolipin is specifically required for electron transfer in mitochondria respiratory chain complex I [136]. Respiratory complex III of the mammalian chain contains bound cardiolipin molecules that are essential for the enzyme activity [148]. ROS induced oxidative damage of cardiolipin in mitochondria may be responsible for the observed defect in the activity of complex III [149]. Similarly, complex IV contains tightly bound cardiolipin whose removal results in a change of its structure and function [150].

Today, many diseases in which mitochondrial dysfunction has been associated with cardiolipin peroxidation have been described [151]. It seems that a high concentration of $\mathrm{Ca}^{2+}$ has a negative impact on mitochondrial function related to the cardiolipin peroxidation. A high concentration of $\mathrm{Ca}^{2+}$ together with cardiolipin peroxidation participates in mPTP opening [127]. It has been suggested the cardiolipin associated with the adenine nucleotide translocator (ANT) may be the site at which $\mathrm{Ca}^{2+}$ binds and activates mPTP opening. Binding of $\mathrm{Ca}^{2+}$ to ANT surrounding cardiolipins enhances the mobility of ANT-Cys ${ }^{56}$, which could be a potential pathway of $\mathrm{Ca}^{2+}$ for induction of mPTP opening [152] (Figure 1).

The accumulation of oxidized cardiolipin in the outer mitochondrial membrane (OMM) contributes to $\mathrm{mPTP}$ opening, which is also accompanied by the release of cytochrome c (Cyt c) from mitochondria into the cytosol [153]. The role of cardiolipin in Cyt c releasing from mitochondria seems to be very important in the process of apoptosis $[154,155]$. 
Cardiolipin is required to maintain the proper function of ATP synthase and facilitate its rotation, which is supported by the transmembrane proton gradient $[156,157]$. Cardiolipin is involved in mPTP control via affecting the function of ATP synthase [158,159]. Positive mitochondrial membrane remodeling is associated with an increased membrane fluidity, as well as increased mitochondrial ATP synthase activity in streptozotocin induced pseudohypoxic acute diabetic conditions [160].

\section{The Role of Mitochondrial Permeability Transition Pores in Signaling Processes of Cardioprotection}

Substantial evidence has revealed that the MPTP are associated with the signaling pathway of cardioprotective models and seem to be an end-effector of cardioprotection [161,162]. It has been shown that the inhibition of $\mathrm{mPTP}$ opening not only provides a protective strategy against reperfusion injury [163], but is also a key point in cardioprotective mechanisms such as IPC or MPC [164-166] (Figure 1). The cardioprotective effect of RPC has been associated with the inhibition of mPTP formation [44]. Transient mPTP opening, which allows the release of $\mathrm{Ca}^{2+}$ from the mitochondria into the matrix, appears to be a key mechanism in MPC [167].

Under physiological conditions, the mPTP are closed or not present. Their opening is associated with postischemic reperfusion, when the perturbations in intracellular $\mathrm{Ca}^{2+}$ homeostasis, ROS accumulation, and a reduction of mitochondrial membrane potential $(\Delta \psi)$ are characteristic $[168,169]$. The massive opening of mPTP results in an increase in IMM permeability and the entry of metabolites into the mitochondrial matrix, which leads to mitochondrial swelling, collapse of $\Delta \psi$, reduction in the efficiency of ATP production by uncoupling the electron transport system from oxidative phosphorylation [170-172], and cell death [10,168]. mPTP remain closed due to low intracellular $\mathrm{pH}(<7.0)$ during ischemia, but they are opened during the first minutes of reperfusion associated with the normalization of $\mathrm{pH}$, which causes irreversible heart damage $[162,173,174]$. Although mPTP are associated with mitochondrial damage and cell death, transient mPTP opening represents one of the physiological processes that is used in the mitochondria of healthy cells [170]. In the heart, transient mPTP opening during preconditioning could be a protective tool that ensures a physiological role during damage [175]. It is believed that transient mPTP opening releases $\mathrm{Ca}^{2+}$ from the mitochondrial matrix to maintain mitochondrial homeostasis. Transient mPTP opening is also associated with a temporary increase in ROS as signaling molecules [176].

Increased $\mathrm{mPTP}$ production has also been reported in the experimental model of acute diabetes mellitus [177]. The increased formation of MPTP is presented as a compensating mechanism that facilitates the transfer of ATP molecules from the mitochondria into the cytosol, where energy supply is currently needed. Residual mitochondrial ATP production due to its increased cytosolic transfer has been shown to be adequate to maintain sufficient levels of adenine nucleotides in acute diabetic myocardium [34]. The inhibition of MPTP opening may also be achieved by pharmacological drugs. The development of inhibitors, except of a prototype compound such as cyclosporine A (CsA), is limited by side effects and a low therapeutic efficacy [178]. Similarly, there is evidence of a protective mechanism of mPTP inhibition against cancer cell survival and proliferation. $\mathrm{MPTP}$ has become a promising strategy for improving cancer therapies [179].

In studies by Heather et al., SSM was adapted to hypoxic conditions and thus mitochondria acquired increased resistance to oxidative damage under conditions of limited oxygen supply. These hypoxia mediated changes induced functional adaptation of mitochondria to a certain dose of stress, resembling the mechanism of the preconditioning effect [180].

mPTP represent a protein complex whose molecular composition remains unexplained. The new knowledge about the structure and regulation of this mitochondrial pore comes annually. The hypothesis about the nature of $\mathrm{mPTP}$ suggests that their number is increasing after a conformational change in ATP synthase after binding of $\mathrm{Ca}^{2+}[181,182]$. This change should lead to the opening of the hidden megachannel. It has been discussed whether the role of ATP synthase can be changed from a key energy producing enzyme to an energy dissipating channel that leads to cell death [182]. ATP synthase, 
together with a phosphate carrier protein $(\mathrm{PiC})$ and $\mathrm{ANT}$, is organized into supramolecular units called synthasomes, which increases the efficiency of ATP production [14,183]. Cyclophilin D (CypD) regulates $\mathrm{MPTP}$, as well as the dynamics of the synthasome, depending on the bioenergy state of mitochondria [184]. Cardiolipin oxidation can disrupt the interactions between the components of the ATP synthasome, which can cause destabilization in this supercomplex, thereby promoting mPTP opening [185].

However, a study by Carroll et al. denied the idea of ATP synthase as the main structural component of MPTP. MPTP opening also occurred after deletion of selected ATP synthase subunits after $\mathrm{Ca}^{2+}$ overload. Based on these findings, the authors unlikely considered that ATP synthase and its subunits are involved in the MPTP structure [186]. Interestingly, new findings confirmed the participation of ANT in the MPTP structure. Results achieved by Karch et al. supported the idea about ANT dependent mPTP activity, which is regulated by CypD. ANT dependent mPTP is activated in response to higher mitochondrial matrix $\mathrm{Ca}^{2+}$ levels, which means independently of CypD [187]. Many question marks hang over the mPTP structure, again.

\section{Unregulated Mitochondrial Permeability Transition Pore Opening}

The prolonged mPTP opening results in disruption of the mitochondrial ultrastructure, halting of mitochondrial energy, and ATP synthesis, resulting in a variety of diseases, currently without successful treatment [188]. The unregulated MPTP opening and the consequent oxidative damage are considered as the major mechanisms of mitochondrial energetic dysfunction, which ultimately lead to cell death $[8,189]$. MPTP opening has an impact on the release of Cyt $\mathrm{c}$ from mitochondria, which is associated with pathophysiological situations such as I/R injury, aging, and other degenerative diseases [127]. One of the independent risk factors that may cause structural, molecular, and biochemical changes is aging. Aging increases CypD expression and its interaction with ATP synthase leading to a higher risk of mPTP opening. Thus, $\mathrm{MPTP}$ are important factors controlling mitochondrial function affected by aging [190]. Cardioprotective mechanisms, such as preconditioning, could be also impaired by aging and lead to defects in protective cell signaling. In a study by Griecsova et al., the efficacy of preconditioning was attenuated in mature adult rats in contrast with younger animals. Increasing age caused the decrease of heart ischemic tolerance, as well as changes in cellular expression of proteins involved in the protective signaling [191]. Age related disorders are also associated with increased ROS production and dysregulation of intracellular $\mathrm{Ca}^{2+}$ levels, resulting in mPTP opening [192]. mPTP are opened during reperfusion after previous ischemic injury of the heart, leading to myocardial damage [193]. Likewise, disruption of $\mathrm{Ca}^{2+}$ homeostasis in addition to myocardial I/R injury also occur in neurodegenerative diseases that lead to mPTP opening [194]. Chronic diseases such as diabetes or hypertension cause changes in mitochondrial bioenergetics manifested by inhibition of respiratory chain complex activity, increased proton leakage from the IMM, increased ROS production, and $\mathrm{Ca}^{2+}$ overload resulting in mPTP opening $[8,172,195]$. It has been found that the prevention of mPTP opening by mPTP inhibitors would be beneficial in a wide range of therapeutically challenging diseases. Therefore, significant effort is being made to develop mPTP specific inhibitors that would overcome the major disadvantages of CsA. Further studies are needed to progress from research to therapeutics $[188,196]$.

\section{Conclusions}

In conclusion, here we emphasize the necessity of maintaining a proper function of cardiac mitochondria even in situations with limited oxygen supply, such as heart ischemic disease. Since it is known that mitochondria have a crucial role in the adaptation process of the heart in unfavorable conditions, the idea of a positive effect of partial oxygen deprivation was studied in new therapeutic approaches. The expression of hypoxic genes and the preference of anaerobic glycolysis associated with the regulation of MPTP are considered as the key mechanisms. The previous findings suggest that not only functional, but also structural changes in cardiac mitochondria are involved in the adaptation 
process. This knowledge is supported by the relation of mitochondrial membrane composition and functional properties of the heart. The composition of the cardiolipin structure, the amount of $\mathrm{mtCx} 43$, and the degree of mitochondrial membrane fluidity affect the formation and opening of mPTP, which is reflected in ATP synthase activity and mitochondrial survival.

Author Contributions: Conceptualization, M.F. and M.J.; resources, M.F., M.J., N.A., and B.S.B.; writing, review and editing, M.F., M.J., N.A., and B.S.B.; visualization, M.F.; supervision, M.F.; project administration, M.F.; funding acquisition, M.F.

Funding: This research was supported by the Scientific Grant Agency of the Ministry of Education, Science Research and Sport of the Slovak Republic VEGA 2/0121/18, VEGA 2/0158/19 and the Slovak Research and Development Agency APVV 15-0119; as well as projects of Structural Funds ITMS 26230120009.

Conflicts of Interest: The authors declare no conflict of interest.

\section{Abbreviations}

AIF, apoptosis-inducing factor; ANT, adenine nucleotide translocator; ATP, adenosine triphosphate; $\mathrm{Ca}^{2+}$, calcium; CsA, cyclosporine A; CypD, cyclophilin D; Cyt c, cytochrome c; Cx43, connexin 43; HIF-1 $\alpha$, hypoxia-inducible factor $1 \alpha$; HSP90, heat shock protein 90; I/R, ischemia/reperfusion; IMM, inner mitochondrial membrane; IPC, ischemic preconditioning; KATP, ATP-sensitive potassium channel; MPC, metabolic preconditioning; $\mathrm{mPTP}$, mitochondrial permeability transition pores; $\mathrm{mtC} \times 43$, mitochondrial connexin $43 ; \mathrm{NADH}$, nicotinamide adenine dinucleotide; $\mathrm{NO}$, nitric oxide; OMM, outer mitochondrial membrane; $\mathrm{PDH}$, pyruvate dehydrogenase; PiC, phosphate carrier protein; ROS, reactive oxygen species; RPC, remote ischemic preconditioning; SSM, subsarcolemmal mitochondria; $\Delta \psi$, mitochondrial membrane potential.

\section{References}

1. Wang, X. The expanding role of mitochondria in apoptosis. Genes Dev. 2001, 15, 2922-2933. [PubMed]

2. Karch, J.; Molkentin, J.D. Regulated necrotic cell death. Circ. Res. 2015, 116, 1800-1809. [CrossRef] [PubMed]

3. Siasos, G.; Tsigkou, V.; Kosmopoulos, M.; Theodosiadis, D.; Simantiris, S.; Tagkou, N.M.; Tsimpiktsioglou, A.; Stampouloglou, P.K.; Oikonomou, E.; Mourouzis, K.; et al. Mitochondria and cardiovascular diseases-From pathophysiology to treatment. Ann. Transl. Med. 2018, 6, 256. [CrossRef] [PubMed]

4. Meerson, F.Z.; Malyshev, I.Y.; Zamotrinsky, A.V. Adaptive protection of the heart and stabilization of myocardial structures. Basic Res. Cardiol. 1991, 86, 87-98. [CrossRef]

5. Wallace, D.C. A mitochondrial paradigm of metabolic and degenerative diseases, aging, and cancer: A dawn for evolutionary medicine. Annu. Rev. Genet. 2005, 39, 359-407. [CrossRef]

6. Ferree, A.; Shirihai, O. Mitochondrial dynamics: The intersection of form and function. In Advances in Experimental Medicine and Biology; Springer: Berlin, Germany, 2012; Volume 748, pp. 13-40.

7. Picard, M.; McEwen, B.S.; Epel, E.S.; Sandi, C. An energetic view of stress: Focus on mitochondria. Front. Neuroendocrinol. 2018, 49, 72-85. [CrossRef]

8. Kwong, J.Q.; Molkentin, J.D. Physiological and pathological roles of the mitochondrial permeability transition pore in the heart. Cell Metab. 2015, 21, 206-214. [CrossRef]

9. Ferdinandy, P.; Schulz, R.; Baxter, G.F. Interaction of cardiovascular risk factors with myocardial ischemia/reperfusion injury, preconditioning, and postconditioning. Pharmacol. Rev. 2007, 59, 418-458. [CrossRef]

10. Halestrap, A.P. What is the mitochondrial permeability transition pore? J. Mol. Cell. Cardiol. 2009, 46, 821-831. [CrossRef]

11. Perrelli, M.-G. Ischemia/reperfusion injury and cardioprotective mechanisms: Role of mitochondria and reactive oxygen species. World J. Cardiol. 2011, 3, 186. [CrossRef]

12. Giaccia, A.J. The biology of hypoxia: The role of oxygen sensing in development, normal function, and disease. Genes Dev. 2004, 18, 2183-2194. [CrossRef] [PubMed]

13. Fuhrmann, D.C.; Brüne, B. Mitochondrial composition and function under the control of hypoxia. Redox Biol. 2017, 12, 208-215. [CrossRef] [PubMed]

14. Paradies, G.; Paradies, V.; Ruggiero, F.M.; Petrosillo, G. Role of cardiolipin in mitochondrial function and dynamics in health and disease: Molecular and pharmacological aspects. Cells 2019, 8, 728. [CrossRef] [PubMed] 
15. Paradies, G.; Petrosillo, G.; Paradies, V.; Ruggiero, F.M. Role of cardiolipin peroxidation and $\mathrm{Ca}^{2+}$ in mitochondrial dysfunction and disease. Cell Calcium 2009, 45, 643-650. [CrossRef]

16. Assaly, R.; de Tassigny, A.D.A.; Paradis, S.; Jacquin, S.; Berdeaux, A.; Morin, D. Oxidative stress, mitochondrial permeability transition pore opening and cell death during hypoxia-reoxygenation in adult cardiomyocytes. Eur. J. Pharmacol. 2012, 675, 6-14. [CrossRef]

17. Gadicherla, A.K.; Wang, N.; Bulic, M.; Agullo-Pascual, E.; Lissoni, A.; De Smet, M.; Delmar, M.; Bultynck, G.; Krysko, D.V.; Camara, A.; et al. Mitochondrial Cx43 hemichannels contribute to mitochondrial calcium entry and cell death in the heart. Basic Res. Cardiol. 2017, 112, 27. [CrossRef]

18. Ardehali, A.; Ports, T.A. Myocardial Oxygen Supply and Demand ${ }^{*}$ Cardiovascular Research Institute, and Division of Cardiology, Department of Medicine, University of California, San Francisco. Chest 1990, 98, 699-705. [CrossRef]

19. Manneschi, L.; Federico, A. Polarographic analyses of subsarcolemmal and intermyofibrillar mitochondria from rat skeletal and cardiac muscle. J. Neurol. Sci. 1995, 128, 151-156. [CrossRef]

20. Kueh, H.Y.; Niethammer, P.; Mitchison, T.J. Maintenance of mitochondrial oxygen homeostasis by cosubstrate compensation. Biophys. J. 2013, 104, 1338-1348. [CrossRef]

21. Riva, A.; Tandler, B.; Loffredo, F.; Vazquez, E.; Hoppel, C. Structural differences in two biochemically defined populations of cardiac mitochondria. Am. J. Physiol. Circ. Physiol. 2005, 289, H868-H872. [CrossRef]

22. Huss, J.M.; Kelly, D.P. Mitochondrial energy metabolism in heart failure: A question of balance. J. Clin. Investig. 2005, 115, 547-555. [CrossRef] [PubMed]

23. Barth, E. Ultrastructural quantitation of mitochondria and myofilaments in cardiac muscle from 10 different animal species including man. J. Mol. Cell. Cardiol. 1992, 24, 669-681. [CrossRef]

24. Ferrari, R.; Cargnoni, A.; Ceconi, C. Anti-ischaemic effect of ivabradine. Pharmacol. Res. 2006, 53, 435-439. [CrossRef] [PubMed]

25. Dedkova, E.N.; Blatter, L.A. Measuring mitochondrial function in intact cardiac myocytes. J. Mol. Cell. Cardiol. 2012, 52, 48-61. [CrossRef]

26. Saks, V.; Favier, R.; Guzun, R.; Schlattner, U.; Wallimann, T. Molecular system bioenergetics: Regulation of substrate supply in response to heart energy demands. J. Physiol. 2006, 577, 769-777. [CrossRef]

27. Kojić, Z.; Kojić, Z.; Kojić, Z.; Šćepanović, L.; Šćepanović, L.; Šćepanović, L.; Popović, N.; Popović, N.; Popović, N. Myocardial oxygen consumption regulation in isolated mouse heart: Assessment by intracoronary administration of exogenous nitric oxide. Acta Physiol. Hung. 2006, 93, 263-270. [CrossRef]

28. Ventura-Clapier, R.; Garnier, A.; Veksler, V.; Joubert, F. Bioenergetics of the failing heart. Biochim. Biophys. Acta Mol. Cell Res. 2011, 1813, 1360-1372. [CrossRef]

29. Stanley, W.C.; Recchia, F.A.; Lopaschuk, G.D. Myocardial substrate metabolism in the normal and failing heart. Physiol. Rev. 2005, 85, 1093-1129. [CrossRef]

30. Hoppel, C.L.; Tandler, B.; Fujioka, H.; Riva, A. Dynamic organization of mitochondria in human heart and in myocardial disease. Int. J. Biochem. Cell Biol. 2009, 41, 1949-1956. [CrossRef]

31. Schanze, N.; Bode, C.; Duerschmied, D. Platelet contributions to myocardial ischemia/reperfusion injury. Front. Immunol. 2019, 10, 1260. [CrossRef]

32. Cerychova, R.; Pavlinkova, G. HIF-1, metabolism, and diabetes in the embryonic and adult heart. Front. Endocrinol. 2018, 9, 460. [CrossRef] [PubMed]

33. Nyengaard, J.R.; Ido, Y.; Kilo, C.; Williamson, J.R. Interactions between hyperglycemia and hypoxia: Implications for diabetic retinopathy. Diabetes 2004, 53, 2931-2938. [CrossRef] [PubMed]

34. Ziegelhöffer, A.; Waczulíková, I.; Ferko, M.; Kincelová, D.; Ziegelhöffer, B.; Ravingerová, T.; Cagalinec, M.; Schönburg, M.; Ziegelhoeffer, T.; Šikurová, L.; et al. Calcium signaling-mediated endogenous protection of cell energetics in the acutely diabetic myocardiumThis article is one of a selection of papers published in a special issue on Advances in Cardiovascular Research. Can. J. Physiol. Pharmacol. 2009, 87, 1083-1094. [CrossRef] [PubMed]

35. Forini, F.; Nicolini, G.; Iervasi, G. Mitochondria as key targets of cardioprotection in cardiac ischemic disease: Role of thyroid hormone triiodothyronine. Int. J. Mol. Sci. 2015, 16, 6312-6336. [CrossRef]

36. Murry, C.E.; Jennings, R.B.; Reimer, K.A. Preconditioning with ischemia: A delay of lethal cell injury in ischemic myocardium. Circulation 1986, 74, 1124-1136. [CrossRef]

37. Honda, H.M.; Korge, P.; Weiss, J.N. Mitochondria and Ischemia/Reperfusion Injury. Ann. N. Y. Acad. Sci. 2005, 1047, 248-258. [CrossRef] 
38. Ravingerová, T.; Pancza, D.; Ziegelhoffer, A.; Styk, J. Preconditioning modulates susceptibility to ischemia-induced arrhythmias in the rat heart: The role of $\alpha$-adrenergic stimulation and K(ATP) channels. Physiol. Res. 2002, 51, 101-119.

39. Waldow, T.; Alexiou, K.; Witt, W.; Albrecht, S.; Wagner, F.; Knaut, M.; Matschke, K. Protection against acute porcine lung ischemia/reperfusion injury by systemic preconditioning via hind limb ischemia. Transpl. Int. 2005, 18, 198-205. [CrossRef]

40. Chen, Q.; Camara, A.K.S.; Stowe, D.F.; Hoppel, C.L.; Lesnefsky, E.J. Modulation of electron transport protects cardiac mitochondria and decreases myocardial injury during ischemia and reperfusion. Am. J. Physiol. Physiol. 2007, 292, C137-C147. [CrossRef]

41. Przyklenk, K.; Bauer, B.; Ovize, M.; Kloner, R.A.; Whittaker, P. Regional ischemic "preconditioning" protects remote virgin myocardium from subsequent sustained coronary occlusion. Circulation 1993, 87, 893-899. [CrossRef]

42. Kharbanda, R.K.; Peters, M.; Walton, B.; Kattenhorn, M.; Mullen, M.; Klein, N.; Vallance, P.; Deanfield, J.; MacAllister, R. Ischemic preconditioning prevents endothelial injury and systemic neutrophil activation during ischemia-reperfusion in humans In Vivo. Circulation 2001, 103, 1624-1630. [CrossRef] [PubMed]

43. Ravingerova, T.; Farkasova, V.; Griecsova, L.; Carnicka, S.; Murarikova, M.; Barlaka, E.; Kolar, F.; Bartekova, M.; Lonek, L.; Slezak, J.; et al. Remote preconditioning as a novel “ conditioning” approach to repair the broken heart: Potential mechanisms and clinical applications. Physiol. Res. 2016, 65, S55-S64. [PubMed]

44. Hausenloy, D.J.; Yellon, D.M. Remote ischaemic preconditioning: Underlying mechanisms and clinical application. Cardiovasc. Res. 2008, 79, 377-386. [CrossRef] [PubMed]

45. Raedschelders, K.; Ansley, D.M.; Chen, D.D.Y. The cellular and molecular origin of reactive oxygen species generation during myocardial ischemia and reperfusion. Pharmacol. Ther. 2012, 133, 230-255. [CrossRef] [PubMed]

46. Consolini, A.E.; Ragone, M.I.; Bonazzola, P.; Colareda, G.A. Mitochondrial bioenergetics during ischemia and reperfusion. In Advances in Experimental Medicine and Biology; Springer: Berlin, Germany, 2017; Volume 982, pp. 141-167.

47. Liu, Y.; Silverstein, F.S.; Skoff, R.; Barks, J.D.E. Hypoxic-ischemic oligodendroglial injury in neonatal rat brain. Pediatr. Res. 2002, 51, 25-33. [CrossRef]

48. Lopaschuk, G.D.; Ussher, J.R.; Folmes, C.D.L.; Jaswal, J.S.; Stanley, W.C. Myocardial fatty acid metabolism in health and disease. Physiol. Rev. 2010, 90, 207-258. [CrossRef]

49. Navarro, A.; Boveris, A. The mitochondrial energy transduction system and the aging process. Am. J. Physiol. Physiol. 2007, 292, C670-C686. [CrossRef]

50. Peterson, L.R.; McKenzie, C.R.; Schaffer, J.E. Diabetic cardiovascular disease: Getting to the heart of the matter. J. Cardiovasc. Transl. Res. 2012, 5, 436-445. [CrossRef]

51. Sugden, M.C.; Holness, M.J. Recent advances in mechanisms regulating glucose oxidation at the level of the pyruvate dehydrogenase complex by PDKs. Am. J. Physiol. Endocrinol. Metab. 2003, 284, E855-E862. [CrossRef]

52. Heather, L.C.; Clarke, K. Metabolism, hypoxia and the diabetic heart. J. Mol. Cell. Cardiol. 2011, 50, 598-605. [CrossRef]

53. Randle, P.J.; Garland, P.B.; Hales, C.N.; Newsholme, E.A. The glucose fatty-acid cycle its role in insulin sensitivity and the metabolic disturbances of diabetes mellitus. Lancet 1963, 281, 785-789. [CrossRef]

54. Jaswal, J.S.; Keung, W.; Wang, W.; Ussher, J.R.; Lopaschuk, G.D. Targeting fatty acid and carbohydrate oxidation-A novel therapeutic intervention in the ischemic and failing heart. Biochim. Biophys. Acta Mol. Cell Res. 2011, 1813, 1333-1350. [CrossRef] [PubMed]

55. Zhou, L.; Huang, H.; McElfresh, T.A.; Prosdocimo, D.A.; Stanley, W.C. Impact of anaerobic glycolysis and oxidative substrate selection on contractile function and mechanical efficiency during moderate severity ischemia. Am. J. Physiol. Circ. Physiol. 2008, 295, H939-H945. [CrossRef] [PubMed]

56. Johannsen, D.L.; Ravussin, E. The role of mitochondria in health and disease. Curr. Opin. Pharmacol. 2009, 9, 780-786. [CrossRef] [PubMed]

57. Giordano, F.J. Oxygen, oxidative stress, hypoxia, and heart failure. J. Clin. Investig. 2005, 115, 500-508. [CrossRef] [PubMed]

58. Jeoung, N.H. Pyruvate dehydrogenase kinases: Therapeutic targets for diabetes and cancers. Diabetes Metab. J. 2015, 39, 188. [CrossRef] [PubMed] 
59. Smolle, M.; Lindsay, J.G. Molecular architecture of the pyruvate dehydrogenase complex: Bridging the gap. Biochem. Soc. Trans. 2006, 34, 815-818. [CrossRef]

60. Jeoung, N.H.; Harris, C.R.; Harris, R.A. Regulation of pyruvate metabolism in metabolic-related diseases. Rev. Endocr. Metab. Disord. 2014, 15, 99-110. [CrossRef]

61. Zheng, J. Energy metabolism of cancer: Glycolysis versus oxidative phosphorylation (Review). Oncol. Lett. 2012, 4, 1151-1157. [CrossRef]

62. Kim, J.; Tchernyshyov, I.; Semenza, G.L.; Dang, C.V. HIF-1-mediated expression of pyruvate dehydrogenase kinase: A metabolic switch required for cellular adaptation to hypoxia. Cell Metab. 2006, 3, 177-185. [CrossRef]

63. Courtnay, R.; Ngo, D.C.; Malik, N.; Ververis, K.; Tortorella, S.M.; Karagiannis, T.C. Cancer metabolism and the Warburg effect: The role of HIF-1 and PI3K. Mol. Biol. Rep. 2015, 42, 841-851. [CrossRef] [PubMed]

64. Dodd, M.S.; da Sousa Fialho, M.L.; Montes Aparicio, C.N.; Kerr, M.; Timm, K.N.; Griffin, J.L.; Luiken, J.J.F.P.; Glatz, J.F.C.; Tyler, D.J.; Heather, L.C. Fatty acids prevent hypoxia-inducible Factor- $1 \alpha$ signaling through decreased succinate in diabetes. JACC Basic Transl. Sci. 2018, 3, 485-498. [CrossRef] [PubMed]

65. Warburg, O. On the origin of cancer cells. Science 1956, 123, 309-314. [CrossRef] [PubMed]

66. Denko, N.C. Hypoxia, HIF1 and glucose metabolism in the solid tumour. Nat. Rev. Cancer 2008, 8, 705-713. [CrossRef]

67. Papandreou, I.; Cairns, R.A.; Fontana, L.; Lim, A.L.; Denko, N.C. HIF-1 mediates adaptation to hypoxia by actively downregulating mitochondrial oxygen consumption. Cell Metab. 2006, 3, 187-197. [CrossRef]

68. Vander Heiden, M.G.; Cantley, L.C.; Thompson, C.B. Understanding the warburg effect: The metabolic requirements of cell proliferation. Science 2009, 324, 1029-1033. [CrossRef]

69. Wittig, R.; Coy, J.F. The role of glucose metabolism and glucose-associated signalling in cancer. Perspect. Medicin. Chem. 2007, 1. [CrossRef]

70. Liberti, M.V.; Locasale, J.W. The warburg effect: How does it benefit cancer cells? Trends Biochem. Sci. 2016, 41, 211-218. [CrossRef]

71. Gunaydin, B.; Çakici, I.; Soncul, H.; Kalaycioglu, S.; Çevik, C.; Sancak, B.; Kanzik, I.; Karadenizli, Y. Does remote organ ischemia trigger cardiac preconditioning during coronary artery surgery? Pharmacol. Res. 2000, 41, 493-496. [CrossRef]

72. Doenst, T.; Nguyen, T.D.; Abel, E.D. Cardiac metabolism in heart failure. Circ. Res. 2013, 113, 709-724. [CrossRef]

73. Daşu, A.; Toma-Daşu, I.; Karlsson, M. Theoretical simulation of tumour oxygenation and results from acute and chronic hypoxia. Phys. Med. Biol. 2003, 48, 2829-2842. [PubMed]

74. Yan, L.-J.; Wu, J.; Jin, Z.; Zheng, H. Sources and implications of NADH/NAD+ redox imbalance in diabetes and its complications. Diabetes Metab. Syndr. Obes. Targets Ther. 2016, 9, 145-153. [CrossRef] [PubMed]

75. Williamson, J.R.; Chang, K.; Frangos, M.; Hasan, K.S.; Ido, Y.; Kawamura, T.; Nyengaard, J.R.; van Den Enden, M.; Kilo, C.; Tilton, R.G. Hyperglycemic pseudohypoxia and diabetic complications. Diabetes 1993, 42, 801-813. [CrossRef] [PubMed]

76. Sivitz, W.I.; Yorek, M.A. Mitochondrial dysfunction in diabetes: From molecular mechanisms to functional significance and therapeutic opportunities. Antioxid. Redox Signal. 2010, 12, 537-577. [CrossRef] [PubMed]

77. McFate, T.; Mohyeldin, A.; Lu, H.; Thakar, J.; Henriques, J.; Halim, N.D.; Wu, H.; Schell, M.J.; Tsang, T.M.; Teahan, O.; et al. Pyruvate dehydrogenase complex activity controls metabolic and malignant phenotype in cancer cells. J. Biol. Chem. 2008, 283, 22700-22708. [CrossRef] [PubMed]

78. Peters, S.J.; Harris, R.A.; Wu, P.; Pehleman, T.L.; Heigenhauser, G.J.F.; Spriet, L.L. Human skeletal muscle $\mathrm{PDH}$ kinase activity and isoform expression during a 3-day high-fat/low-carbohydrate diet. Am. J. Physiol. Endocrinol. Metab. 2001, 281, E1151-E1158. [CrossRef] [PubMed]

79. Park, S.; Jeon, J.-H.; Min, B.-K.; Ha, C.-M.; Thoudam, T.; Park, B.-Y.; Lee, I.-K. Role of the pyruvate dehydrogenase complex in metabolic remodeling: Differential pyruvate dehydrogenase complex functions in metabolism. Diabetes Metab. J. 2018, 42, 270. [CrossRef]

80. Lee, I.-K. The role of pyruvate dehydrogenase kinase in diabetes and obesity. Diabetes Metab. J. 2014, 38, 181. [CrossRef]

81. Sun, W.; Liu, Q.; Leng, J.; Zheng, Y.; Li, J. The role of Pyruvate Dehydrogenase Complex in cardiovascular diseases. Life Sci. 2015, 121, 97-103. [CrossRef] 
82. Hwang, S.; Lee, S.-G.; Belghiti, J. Liver transplantation for HCC: Its role. J. Hepatobiliary Pancreat. Sci. 2010, 17, 443-448. [CrossRef]

83. Ham, P.B.; Raju, R. Mitochondrial function in hypoxic ischemic injury and influence of aging. Prog. Neurobiol. 2017, 157, 92-116. [CrossRef] [PubMed]

84. Malfitano, C.; de Souza Junior, A.L.; Carbonaro, M.; Bolsoni-Lopes, A.; Figueroa, D.; de Souza, L.E.; Silva, K.A.S.; Consolim-Colombo, F.; Curi, R.; Irigoyen, M.C. Glucose and fatty acid metabolism in infarcted heart from streptozotocin-induced diabetic rats after 2 weeks of tissue remodeling. Cardiovasc. Diabetol. 2015, 14, 149. [CrossRef] [PubMed]

85. Xu, G.; Takashi, E.; Kudo, M.; Ishiwata, T.; Naito, Z. Contradictory effects of short-and long-term hyperglycemias on ischemic injury of myocardium via intracellular signaling pathway. Exp. Mol. Pathol. 2004, 76, 57-65. [CrossRef] [PubMed]

86. Ferko, M.; Habodászová, D.; Waczulíková, I.; Mujkošová, J.; Kucharská, J.; Šikurová, L.; Ziegelhoffer, B.; Styk, J.; Ziegelhffer, A. Endogenous protective mechanisms in remodeling of rat heart mitochondrial membranes in the acute phase of streptozotocin-induced diabetes. Physiol. Res. 2008, 57, S67-S73. [PubMed]

87. Zhu, X.-H.; Yuan, H.-J.; Wu, Y.-N.; Kang, Y.; Jiao, J.-J.; Gao, W.-Z.; Liu, Y.-X.; Lou, J.-S.; Xia, Z. Non-invasive limb ischemic pre-conditioning reduces oxidative stress and attenuates myocardium ischemia-reperfusion injury in diabetic rats. Free Radic. Res. 2011, 45, 201-210. [CrossRef] [PubMed]

88. King, A.J.F. The use of animal models in diabetes research. Br. J. Pharmacol. 2012, 166, 877-894. [CrossRef]

89. Kadowaki, T.; Kasuga, M.; Akanuma, Y.; Ezaki, O.; Takaku, F. Decreased autophosphorylation of the insulin receptor-kinase in streptozotocin-diabetic rats. J. Biol. Chem. 1984, 259, 14208-14216.

90. Ziegelhöffer, A.; Ravingerová, T.; Styk, J.; Tribulová, N.; Volkovová, K.; Šeboková, J.; Breier, A. Diabetic cardiomyopathy in rats: Biochemical mechanisms of increased tolerance to calcium overload. Diabetes Res. Clin. Pract. 1996, 31, S93-S103. [CrossRef]

91. Oliveira, P.J.; Seiça, R.; Coxito, P.M.; Rolo, A.P.; Palmeira, C.M.; Santos, M.S.; Moreno, A.J.M. Enhanced permeability transition explains the reduced calcium uptake in cardiac mitochondria from streptozotocin-induced diabetic rats. FEBS Lett. 2003, 554, 511-514. [CrossRef]

92. Rodrigues, B.; Figueroa, D.M.T.; Fang, J.; Rosa, K.T.; Llesuy, S.; De Angelis, K.; Irigoyen, M.C. Short-term diabetes attenuates left ventricular dysfunction and mortality rates after myocardial infarction in rodents. Clinics 2011, 66, 1437-1442. [CrossRef]

93. Malfitano, C.; Barboza, C.A.; Mostarda, C.; da Palma, R.K.; dos Santos, C.P.; Rodrigues, B.; Freitas, S.C.F.; Belló-Klein, A.; Llesuy, S.; Irigoyen, M.-C.; et al. Diabetic hyperglycemia attenuates sympathetic dysfunction and oxidative stress after myocardial infarction in rats. Cardiovasc. Diabetol. 2014, 13, 131. [CrossRef] [PubMed]

94. Tani, M.; Neely, J.R. Hearts from diabetic rats are more resistant to in vitro ischemia: Possible role of altered $\mathrm{Ca}^{2+}$ metabolism. Circ. Res. 1988, 62, 931-940. [CrossRef] [PubMed]

95. Kancirová, I.; Jašová, M.; Muráriková, M.; Sumbalová, Z.; Uličná, O.; Ravingerová, T.; Waczulíková, I.; Ziegelhöffer, A.; Ferko, M. Cardioprotection induced by remote ischemic preconditioning preserves the mitochondrial respiratory function in acute diabetic myocardium. Physiol. Res. 2016, 65, S611-S619. [PubMed]

96. Ferko, M.; Gvozdjaková, A.; Kucharská, J.; Mujkošová, J.; Waczulíková, I.; Styk, J.; Ravingerová, T.; Ziegelhöffer-Mihalovičová, B.; Ziegelhöffer, A. Functional remodeling of heart mitochondria in acute diabetes: Interrelationships between damage endogenous protection and adaptation. Gen. Physiol. Biophys. 2006, 25, 397-413.

97. Mapanga, R.F.; Rajamani, U.; Dlamini, N.; Zungu-Edmondson, M.; Kelly-Laubscher, R.; Shafiullah, M.; Wahab, A.; Hasan, M.Y.; Fahim, M.A.; Rondeau, P.; et al. Oleanolic acid: A novel cardioprotective agent that blunts hyperglycemia-induced contractile dysfunction. PLoS ONE 2012, 7, e47322. [CrossRef]

98. Severs, N.J.; Bruce, A.F.; Dupont, E.; Rothery, S. Remodelling of gap junctions and connexin expression in diseased myocardium. Cardiovasc. Res. 2008, 80, 9-19. [CrossRef]

99. Tribulova, N.; Szeiffova Bacova, B.; Egan Benova, T.; Knezl, V.; Barancik, M.; Slezak, J. Omega-3 index and anti-arrhythmic potential of omega-3 PUFAs. Nutrients 2017, 9, 1191. [CrossRef]

100. Katengua-Thamahane, E.; Szeiffova Bacova, B.; Bernatova, I.; Sykora, M.; Knezl, V.; Van Rooyen, J.; Tribulova, N. Effects of red palm oil on myocardial antioxidant enzymes, nitric oxide synthase and heart function in spontaneously hypertensive rats. Int. J. Mol. Sci. 2017, 18, 2476. [CrossRef] 
101. Sykora, M.; Szeiffova Bacova, B.; Egan Benova, T.; Barancik, M.; Zurmanova, J.; Rauchova, H.; Weismann, P.; Pavelka, S.; Kurahara, L.H.; Slezak, J.; et al. Cardiac Cx43 and ECM Responses to Altered Thyroid Status Are Blunted in Spontaneously Hypertensive versus Normotensive Rats. Int. J. Mol. Sci. 2019, 20, 3758. [CrossRef]

102. Prado, N.J.; Egan Beňová, T.; Diez, E.R.; Knezl, V.; Lipták, B.; Ponce Zumino, A.Z.; Llamedo-Soria, M.; Szeiffová Bačová, B.; Miatello, R.M.; Tribulová, N. Melatonin receptor activation protects against low potassium-induced ventricular fibrillation by preserving action potentials and connexin- 43 topology in isolated rat hearts. J. Pineal Res. 2019, 67. [CrossRef]

103. Laird, D.W. Life cycle of connexins in health and disease. Biochem. J. 2006, 394, 527-543. [CrossRef] [PubMed]

104. Veenstra, R.D.; Wang, H.-Z.; Beblo, D.A.; Chilton, M.G.; Harris, A.L.; Beyer, E.C.; Brink, P.R. Selectivity of connexin-specific gap junctions does not correlate with channel conductance. Circ. Res. 1995, 77, 1156-1165. [CrossRef] [PubMed]

105. Goodenough, D.A. Connexins, connexons, and intercellular communication. Annu. Rev. Biochem. 1996, 65, 475-502. [CrossRef] [PubMed]

106. Severs, N. Gap junction alterations in human cardiac disease. Cardiovasc. Res. 2004, 62, 368-377. [CrossRef]

107. Sáez, J.C.; Retamal, M.A.; Basilio, D.; Bukauskas, F.F.; Bennett, M.V.L. Connexin-based gap junction hemichannels: Gating mechanisms. Biochim. Biophys. Acta Biomembr. 2005, 1711, 215-224. [CrossRef]

108. Boengler, K.; Dodoni, G.; Rodriguezsinovas, A.; Cabestrero, A.; Ruizmeana, M.; Gres, P.; Konietzka, I.; Lopeziglesias, C.; Garciadorado, D.; Dilisa, F. Connexin 43 in cardiomyocyte mitochondria and its increase by ischemic preconditioning. Cardiovasc. Res. 2005, 67, 234-244. [CrossRef]

109. Ruiz-Meana, M.; Rodriguez-Sinovas, A.; Cabestrero, A.; Boengler, K.; Heusch, G.; Garcia-Dorado, D. Mitochondrial connexin 43 as a new player in the pathophysiology of myocardial ischaemia-reperfusion injury. Cardiovasc. Res. 2007, 77, 325-333. [CrossRef]

110. Boengler, K.; Stahlhofen, S.; Sand, A.; Gres, P.; Ruiz-Meana, M.; Garcia-Dorado, D.; Heusch, G.; Schulz, R. Presence of connexin 43 in subsarcolemmal, but not in interfibrillar cardiomyocyte mitochondria. Basic Res. Cardiol. 2009, 104, 141-147. [CrossRef]

111. Rodríguez-Sinovas, A.; Ruiz-Meana, M.; Denuc, A.; García-Dorado, D. Mitochondrial Cx43, an important component of cardiac preconditioning. Biochim. Biophys. Acta Biomembr. 2018, 1860, 174-181. [CrossRef]

112. Boengler, K.; Schulz, R. Connexin 43 and mitochondria in cardiovascular health and disease. In Advances in Experimental Medicine and Biology; Springer: Berlin, Germany, 2017; Volume 982, pp. 227-246.

113. Boengler, K.; Ruiz-Meana, M.; Gent, S.; Ungefug, E.; Soetkamp, D.; Miro-Casas, E.; Cabestrero, A.; Fernandez-Sanz, C.; Semenzato, M.; Di Lisa, F.; et al. Mitochondrial connexin 43 impacts on respiratory complex I activity and mitochondrial oxygen consumption. J. Cell. Mol. Med. 2012, 16, 1649-1655. [CrossRef]

114. Denuc, A.; Núñez, E.; Calvo, E.; Loureiro, M.; Miro-Casas, E.; Guarás, A.; Vázquez, J.; Garcia-Dorado, D. New protein-protein interactions of mitochondrial connexin 43 in mouse heart. J. Cell. Mol. Med. 2016, 20, 794-803. [CrossRef] [PubMed]

115. Guo, R.; Si, R.; Scott, B.T.; Makino, A. Mitochondrial connexin40 regulates mitochondrial calcium uptake in coronary endothelial cells. Am. J. Physiol. Physiol. 2017, 312, C398-C406. [CrossRef] [PubMed]

116. Schulz, R.; Görge, P.M.; Görbe, A.; Ferdinandy, P.; Lampe, P.D.; Leybaert, L. Connexin 43 is an emerging therapeutic target in ischemia/reperfusion injury, cardioprotection and neuroprotection. Pharmacol. Ther. 2015, 153, 90-106. [CrossRef] [PubMed]

117. Heinzel, F.R.; Luo, Y.; Li, X.; Boengler, K.; Buechert, A.; García-Dorado, D.; Di Lisa, F.; Schulz, R.; Heusch, G. Impairment of diazoxide-induced formation of reactive oxygen species and loss of cardioprotection in connexin 43 deficient mice. Circ. Res. 2005, 97, 583-586. [CrossRef]

118. Paggio, A.; Checchetto, V.; Campo, A.; Menabò, R.; Di Marco, G.; Di Lisa, F.; Szabo, I.; Rizzuto, R.; De Stefani, D. Identification of an ATP-sensitive potassium channel in mitochondria. Nature 2019, 572, 609-613. [CrossRef]

119. Korge, P.; Honda, H.M.; Weiss, J.N. Protection of cardiac mitochondria by diazoxide and protein kinase C: Implications for ischemic preconditioning. Proc. Natl. Acad. Sci. USA 2002, 99, 3312-3317. [CrossRef]

120. Kirca, M.; Kleinbongard, P.; Soetkamp, D.; Heger, J.; Csonka, C.; Ferdinandy, P.; Schulz, R. Interaction between Connexin 43 and nitric oxide synthase in mice heart mitochondria. J. Cell. Mol. Med. 2015, 19, 815-825. [CrossRef] 
121. Soetkamp, D.; Nguyen, T.T.; Menazza, S.; Hirschhäuser, C.; Hendgen-Cotta, U.B.; Rassaf, T.; Schlüter, K.D.; Boengler, K.; Murphy, E.; Schulz, R. S-nitrosation of mitochondrial connexin 43 regulates mitochondrial function. Basic Res. Cardiol. 2014, 109, 433. [CrossRef]

122. Katoh, H.; Nishigaki, N.; Hayashi, H. Diazoxide opens the mitochondrial permeability transition pore and alters $\mathrm{Ca}^{2+}$ transients in rat ventricular myocytes. Circulation 2002, 105, 2666-2671. [CrossRef]

123. Srisakuldee, W.; Makazan, Z.; Nickel, B.E.; Zhang, F.; Thliveris, J.A.; Pasumarthi, K.B.S.; Kardami, E. The FGF-2-triggered protection of cardiac subsarcolemmal mitochondria from calcium overload is mitochondrial connexin 43-dependent. Cardiovasc. Res. 2014, 103, 72-80. [CrossRef]

124. Rodriguez-Sinovas, A.; Boengler, K.; Cabestrero, A.; Gres, P.; Morente, M.; Ruiz-Meana, M.; Konietzka, I.; Miró, E.; Totzeck, A.; Heusch, G.; et al. Translocation of connexin 43 to the inner mitochondrial membrane of cardiomyocytes through the heat shock protein 90-dependent TOM pathway and its importance for cardioprotection. Circ. Res. 2006, 99, 93-101. [CrossRef] [PubMed]

125. Kagan, V.E.; Tyurin, V.A.; Jiang, J.; Tyurina, Y.Y.; Ritov, V.B.; Amoscato, A.A.; Osipov, A.N.; Belikova, N.A.; Kapralov, A.A.; Kini, V.; et al. Cytochrome c acts as a cardiolipin oxygenase required for release of proapoptotic factors. Nat. Chem. Biol. 2005, 1, 223-232. [CrossRef] [PubMed]

126. Houtkooper, R.H.; Vaz, F.M. Cardiolipin, the heart of mitochondrial metabolism. Cell. Mol. Life Sci. 2008, 65, 2493-2506. [CrossRef] [PubMed]

127. Paradies, G.; Paradies, V.; De Benedictis, V.; Ruggiero, F.M.; Petrosillo, G. Functional role of cardiolipin in mitochondrial bioenergetics. Biochim. Biophys. Acta Bioenerg. 2014, 1837, 408-417. [CrossRef]

128. Unsay, J.D.; Cosentino, K.; Subburaj, Y.; García-Sáez, A.J. Cardiolipin effects on membrane structure and dynamics. Langmuir 2013, 29, 15878-15887. [CrossRef]

129. Giorgio, V.; Guo, L.; Bassot, C.; Petronilli, V.; Bernardi, P. Calcium and regulation of the mitochondrial permeability transition. Cell Calcium 2018, 70, 56-63. [CrossRef]

130. Ferko, M.; Farkasova, V.; Jasova, M.; Kancirova, I.; Ravingerova, T.; Adameova, A.D.; Andelova, N.; Waczulikova, I. Hypercholesterolemia antagonized heart adaptation and functional remodeling of the mitochondria observed in acute diabetes mellitus subjected to ischemia/reperfusion injury. J. Physiol. Pharmacol. 2018, 69, 685-697.

131. Palovicova, V.; Bardelcikova, A.; Obernauerova, M. Absence of anionic phospholipids in Kluyveromyces lactis cells is fatal without F1-catalysed ATP hydrolysis. Can. J. Microbiol. 2012, 58, 694-702. [CrossRef]

132. Jones, R.M.; Bagchi, M.; Das, D.K. Preconditioning of heart by repeated stunning: Adaptive modification of myocardial lipid membrane. Basic Res. Cardiol. 1992, 87, 527-535. [CrossRef]

133. Muráriková, M.; Ferko, M.; Waczulíková, I.; Jašová, M.; Kancirová, I.; Murínová, J.; Ravingerová, T. Changes in mitochondrial properties may contribute to enhanced resistance to ischemia-reperfusion injury in the diabetic rat heart. Can. J. Physiol. Pharmacol. 2017, 95, 969-976. [CrossRef]

134. Schenkel, L.C.; Bakovic, M. Formation and regulation of mitochondrial membranes. Int. J. Cell Biol. 2014, 2014, 1-13. [CrossRef] [PubMed]

135. Lesnefsky, E.J.; Slabe, T.J.; Stoll, M.S.K.; Minkler, P.E.; Hoppel, C.L. Myocardial ischemia selectively depletes cardiolipin in rabbit heart subsarcolemmal mitochondria. Am. J. Physiol. Hear Circ. Physiol. 2001, 280, H2770-H2778. [CrossRef] [PubMed]

136. Paradies, G.; Petrosillo, G.; Pistolese, M.; Di Venosa, N.; Federici, A.; Ruggiero, F.M. Decrease in mitochondrial complex i activity in ischemic/reperfused rat heart. Circ. Res. 2004, 94, 53-59. [CrossRef] [PubMed]

137. Cao, S.G.; Cheng, P.; Angel, A.; Hatch, G.M. Thyroxine stimulates phosphatidylglycerolphosphate synthase activity in rat heart mitochondria. Biochim. Biophys. Acta Lipids Lipid Metab. 1995, 1256, 241-244. [CrossRef]

138. Hostetler, K.Y. Effect of thyroxine on the activity of mitochondrial cardiolipin synthase in rat liver. Biochim. Biophys. Acta Lipids Lipid Metab. 1991, 1086, 139-140. [CrossRef]

139. He, Q.; Han, X. Cardiolipin remodeling in diabetic heart. Chem. Phys. Lipids 2014, 179, 75-81. [CrossRef]

140. Lesnefsky, E.J.; Chen, Q.; Hoppel, C.L. Mitochondrial metabolism in aging heart. Circ. Res. 2016, 118, 1593-1611. [CrossRef]

141. Dolinsky, V.W.; Cole, L.K.; Sparagna, G.C.; Hatch, G.M. Cardiac mitochondrial energy metabolism in heart failure: Role of cardiolipin and sirtuins. Biochim. Biophys. Acta Mol. Cell Biol. Lipids 2016, 1861, 1544-1554. [CrossRef]

142. Yin, H.; Zhu, M. Free radical oxidation of cardiolipin: Chemical mechanisms, detection and implication in apoptosis, mitochondrial dysfunction and human diseases. Free Radic. Res. 2012, 46, 959-974. [CrossRef] 
143. Fajardo, V.A.; Mikhaeil, J.S.; Leveille, C.F.; Saint, C.; LeBlanc, P.J. Cardiolipin content, linoleic acid composition, and tafazzin expression in response to skeletal muscle overload and unload stimuli. Sci. Rep. 2017, 7, 2060. [CrossRef]

144. Dudek, J. Role of cardiolipin in mitochondrial signaling pathways. Front. Cell Dev. Biol. 2017, 5, 90. [CrossRef] [PubMed]

145. Patil, V.A.; Greenberg, M.L. Cardiolipin-mediated cellular signaling. Adv. Exp. Med. Biol. 2013, 991, $195-213$. [PubMed]

146. Sparagna, G.C.; Lesnefsky, E.J. Cardiolipin remodeling in the heart. J. Cardiovasc. Pharmacol. 2009, 53, 290-301. [CrossRef] [PubMed]

147. Zhang, M.; Mileykovskaya, E.; Dowhan, W. Gluing the respiratory chain together. J. Biol. Chem. 2002, 277, 43553-43556. [CrossRef]

148. Gomez, B.; Robinson, N.C. Phospholipase digestion of bound cardiolipin reversibly inactivates bovine cytochrome bc 1 †. Biochemistry 1999, 38, 9031-9038. [CrossRef]

149. Petrosillo, G.; Ruggiero, F.M.; Di Venosa, N.; Paradies, G. Decreased complex III activity in mitochondria isolated from rat heart subjected to ischemia and reperfusion: Role of reactive oxygen species and cardiolipin. FASEB J. 2003, 7, 714-716. [CrossRef]

150. Sedlák, E.; Robinson, N.C. Phospholipase A 2 digestion of cardiolipin bound to bovine cytochrome c oxidase alters both activity and quaternary structure t. Biochemistry 1999, 38, 14966-14972. [CrossRef]

151. Chicco, A.J.; Sparagna, G.C. Role of cardiolipin alterations in mitochondrial dysfunction and disease. Am. J. Physiol. Physiol. 2007, 292, C33-C44. [CrossRef]

152. Pestana, C.R.; Silva, C.H.T.P.; Pardo-Andreu, G.L.; Rodrigues, F.P.; Santos, A.C.; Uyemura, S.A.; Curti, C. Ca ${ }^{2+}$ binding to c-state of adenine nucleotide translocase (ANT)-surrounding cardiolipins enhances (ANT)-Cys56 relative mobility: A computational-based mitochondrial permeability transition study. Biochim. Biophys. Acta Bioenerg. 2009, 1787, 176-182. [CrossRef]

153. Ostrander, D.B.; Sparagna, G.C.; Amoscato, A.A.; McMillin, J.B.; Dowhan, W. Decreased cardiolipin synthesis corresponds with cytochrome c release in palmitate-induced cardiomyocyte apoptosis. J. Biol. Chem. 2001, 276, 38061-38067.

154. Ott, M.; Robertson, J.D.; Gogvadze, V.; Zhivotovsky, B.; Orrenius, S. Cytochrome c release from mitochondria proceeds by a two-step process. Proc. Natl. Acad. Sci. USA 2002, 99, 1259-1263. [CrossRef] [PubMed]

155. Ott, M.; Zhivotovsky, B.; Orrenius, S. Role of cardiolipin in cytochrome c release from mitochondria. Cell Death Differ. 2007, 14, 1243-1247. [CrossRef] [PubMed]

156. Smith Eble, K.; Coleman, W.B.; Hantgan, R.R.; Cunningham, C.C. Tightly associated cardiolipin in the bovine heart mitochondrial ATP synthase as analyzed by 31 P nuclear magnetic resonance spectroscopy. J. Biol. Chem. 1990, 265, 19434-19440.

157. Duncan, A.L.; Robinson, A.J.; Walker, J.E. Cardiolipin binds selectively but transiently to conserved lysine residues in the rotor of metazoan ATP synthases. Proc. Natl. Acad. Sci. USA 2016, 113, 8687-8692. [CrossRef]

158. Biasutto, L.; Azzolini, M.; Szabò, I.; Zoratti, M. The mitochondrial permeability transition pore in AD 2016 : An update. Biochim. Biophys. Acta Mol. Cell Res. 2016, 1863, 2515-2530. [CrossRef]

159. Carraro, M.; Checchetto, V.; Szabó, I.; Bernardi, P. F-ATP synthase and the permeability transition pore: Fewer doubts, more certainties. FEBS Lett. 2019, 593, 1542-1553. [CrossRef]

160. Jašová, M.; Kancirová, I.; Waczulíková, I.; Ferko, M. Mitochondria as a target of cardioprotection in models of preconditioning. J. Bioenerg. Biomembr. 2017, 49, 357-368. [CrossRef]

161. Javadov, S.; Karmazyn, M.; Escobales, N. Mitochondrial permeability transition pore opening as a promising therapeutic target in cardiac diseases. J. Pharmacol. Exp. Ther. 2009, 330, 670-678. [CrossRef]

162. Bernardi, P.; Di Lisa, F. The mitochondrial permeability transition pore: Molecular nature and role as a target in cardioprotection. J. Mol. Cell. Cardiol. 2015, 78, 100-106. [CrossRef]

163. Szabo, I.; Zoratti, M. The mitochondrial megachannel is the permeability transition pore. J. Bioenerg. Biomembr. 1992, 24, 111-117. [CrossRef]

164. Javadov, S.; Karmazyn, M. Mitochondrial permeability transition pore opening as an endpoint to initiate cell death and as a putative target for cardioprotection. Cell. Physiol. Biochem. 2007, 20, 1-22. [CrossRef] [PubMed] 
165. Nazari, A.; Sadr, S.S.; Faghihi, M.; Azizi, Y.; Hosseini, M.-J.; Mobarra, N.; Tavakoli, A.; Imani, A. Vasopressin attenuates ischemia-reperfusion injury via reduction of oxidative stress and inhibition of mitochondrial permeability transition pore opening in rat hearts. Eur. J. Pharmacol. 2015, 760, 96-102. [CrossRef] [PubMed]

166. Argaud, L. Preconditioning delays $\mathrm{Ca}^{2+}$-induced mitochondrial permeability transition. Cardiovasc. Res. 2004, 61, 115-122. [CrossRef] [PubMed]

167. Ziegelhöffer-Mihalovičová, B.; Waczulíková, I.; Šikurová, L.; Styk, J.; Čársky, J.; Ziegelhöffer, A. Remodelling of the sarcolemma in diabetic rat hearts: The role of membrane fluidity. Mol. Cell. Biochem. 2003, 249, 175-182. [CrossRef] [PubMed]

168. Naderi, R.; Imani, A.; Faghihi, M.; Moghimian, M. Phenylephrine induces early and late cardioprotection through mitochondrial permeability transition pore in the isolated rat heart. J. Surg. Res. 2010, 164, e37-e42. [CrossRef] [PubMed]

169. Ong, S.-B.; Samangouei, P.; Kalkhoran, S.B.; Hausenloy, D.J. The mitochondrial permeability transition pore and its role in myocardial ischemia reperfusion injury. J. Mol. Cell. Cardiol. 2015, 78, 23-34. [CrossRef]

170. Elrod, J.W.; Molkentin, J.D. Physiologic functions of cyclophilin d and the mitochondrial permeability transition pore. Circ. J. 2013, 77, 1111-1122. [CrossRef]

171. Mnatsakanyan, N.; Beutner, G.; Porter, G.A.; Alavian, K.N.; Jonas, E.A. Physiological roles of the mitochondrial permeability transition pore. J. Bioenerg. Biomembr. 2017, 49, 13-25. [CrossRef]

172. Pérez, M.J.; Quintanilla, R.A. Development or disease: Duality of the mitochondrial permeability transition pore. Dev. Biol. 2017, 426,1-7. [CrossRef]

173. Javadov, S.; Jang, S.; Parodi-Rullán, R.; Khuchua, Z.; Kuznetsov, A.V. Mitochondrial permeability transition in cardiac ischemia-reperfusion: Whether cyclophilin D is a viable target for cardioprotection? Cell. Mol. Life Sci. 2017, 74, 2795-2813. [CrossRef]

174. Halestrap, A.P.; Richardson, A.P. The mitochondrial permeability transition: A current perspective on its identity and role in ischaemia/reperfusion injury. J. Mol. Cell. Cardiol. 2015, 78, 129-141. [CrossRef] [PubMed]

175. Hou, Y.; Ghosh, P.; Wan, R.; Ouyang, X.; Cheng, H.; Mattson, M.P.; Cheng, A. Permeability transition pore-mediated mitochondrial superoxide flashes mediate an early inhibitory effect of amyloid beta1-42 on neural progenitor cell proliferation. Neurobiol. Aging 2014, 35, 975-989. [CrossRef] [PubMed]

176. Lu, X.; Kwong, J.Q.; Molkentin, J.D.; Bers, D.M. Individual cardiac mitochondria undergo rare transient permeability transition pore openings. Circ. Res. 2016, 118, 834-841. [CrossRef] [PubMed]

177. Ziegelhoffer-Mihalovicova, B.; Okruhlicová, L.; Tribulová, N.; Ravingerová, T.; Volkovová, K.; Šeboková, J.; Ziegelhöffer, A. Mitochondrial contact sites detected by creatine phosphokinase activity in the hearts of normal and diabetic rats: Is mitochondrial contact sites formation a calcium-dependent process? Gen. Physiol. Biophys. 1997, 16, 329-338.

178. Briston, T.; Selwood, D.L.; Szabadkai, G.; Duchen, M.R. Mitochondrial permeability transition: A molecular lesion with multiple drug targets. Trends Pharmacol. Sci. 2019, 40, 50-70. [CrossRef]

179. Bonora, M.; Pinton, P. The mitochondrial permeability transition pore and cancer: Molecular mechanisms involved in cell death. Front. Oncol. 2014, 4, 302. [CrossRef]

180. Heather, L.C.; Cole, M.A.; Tan, J.-J.; Ambrose, L.J.A.; Pope, S.; Abd-Jamil, A.H.; Carter, E.E.; Dodd, M.S.; Yeoh, K.K.; Schofield, C.J.; et al. Metabolic adaptation to chronic hypoxia in cardiac mitochondria. Basic Res. Cardiol. 2012, 107, 268. [CrossRef]

181. Jonckheere, A.I.; Smeitink, J.A.M.; Rodenburg, R.J.T. Mitochondrial ATP synthase: Architecture, function and pathology. J. Inherit. Metab. Dis. 2012, 35, 211-225. [CrossRef]

182. Bernardi, P. Why F-ATP Synthase remains a strong candidate as the mitochondrial permeability transition pore. Front. Physiol. 2018, 9, 1543. [CrossRef]

183. Karch, J.; Molkentin, J.D. Identifying the components of the elusive mitochondrial permeability transition pore. Proc. Natl. Acad. Sci. USA 2014, 111, 10396-10397. [CrossRef]

184. Beutner, G.; Alanzalon, R.E.; Porter, G.A. Cyclophilin D regulates the dynamic assembly of mitochondrial ATP synthase into synthasomes. Sci. Rep. 2017, 7, 14488. [CrossRef]

185. Claypool, S.M. Cardiolipin, a critical determinant of mitochondrial carrier protein assembly and function. Biochim. Biophys. Acta Biomembr. 2009, 1788, 2059-2068. [CrossRef] [PubMed]

186. Carroll, J.; He, J.; Ding, S.; Fearnley, I.M.; Walker, J.E. Persistence of the permeability transition pore in human mitochondria devoid of an assembled ATP synthase. Proc. Natl. Acad. Sci. USA 2019, 116, 12816-12821. [CrossRef] [PubMed] 
187. Karch, J.; Bround, M.J.; Khalil, H.; Sargent, M.A.; Latchman, N.; Terada, N.; Peixoto, P.M.; Molkentin, J.D. Inhibition of mitochondrial permeability transition by deletion of the ANT family and CypD. Sci. Adv. 2019, 5, eaaw4597. [CrossRef]

188. Šileikyte, J.; Forte, M. The mitochondrial permeability transition in mitochondrial disorders. Oxidative Med. Cell. Longev. 2019, 2019, 11. [CrossRef]

189. Penna, C.; Perrelli, M.-G.; Pagliaro, P. Mitochondrial pathways, permeability transition pore, and redox signaling in cardioprotection: Therapeutic implications. Antioxid. Redox Signal. 2013, 18, 556-599. [CrossRef] [PubMed]

190. Gauba, E.; Guo, L.; Du, H. Cyclophilin D promotes brain mitochondrial F1FO ATP synthase dysfunction in aging mice. J. Alzheimer Dis. 2016, 55, 1351-1362. [CrossRef] [PubMed]

191. Griecsová, L.; Farkašová, V.; Gáblovskỳ, I.; Khandelwal, V.K.M.; Bernátová, I.; Tatarková, Z.; Kaplan, P.; Ravingerová, T. Effect of maturation on the resistance of rat hearts against ischemia. Study of potential molecular mechanisms. Physiol. Res. 2015, 64, S685-S696.

192. Müller, M.; Ahumada-Castro, U.; Sanhueza, M.; Gonzalez-Billault, C.; Court, F.A.; Cárdenas, C. Mitochondria and calcium regulation as basis of neurodegeneration associated with aging. Front. Neurosci. 2018, 12, 470. [CrossRef] [PubMed]

193. Griffiths, E.J.; Halestrap, A.P. Protection by cyclosporin a of ischemia/reperfusion-induced damage in isolated rat hearts. J. Mol. Cell. Cardiol. 1993, 25, 1461-1469. [CrossRef]

194. Abeti, R.; Abramov, A.Y. Mitochondrial $\mathrm{Ca}^{2+}$ in neurodegenerative disorders. Pharmacol. Res. 2015, 99, 377-381. [CrossRef] [PubMed]

195. Walters, A.M.; Porter, G.A.; Brookes, P.S. Mitochondria as a drug target in ischemic heart disease and cardiomyopathy. Circ. Res. 2012, 111, 1222-1236. [CrossRef] [PubMed]

196. Bhosale, G.; Duchen, M.R. Investigating the mitochondrial permeability transition pore in disease phenotypes and drug screening. Curr. Protoc. Pharmacol. 2019, 85, e59. [CrossRef] [PubMed]

(C) 2019 by the authors. Licensee MDPI, Basel, Switzerland. This article is an open access article distributed under the terms and conditions of the Creative Commons Attribution (CC BY) license (http://creativecommons.org/licenses/by/4.0/). 